\title{
REMOVAL OF MERCURY FROM AQUEOUS SOLUTIONS BY SHREDDED RUBBER
}

E. R. RUSSELL
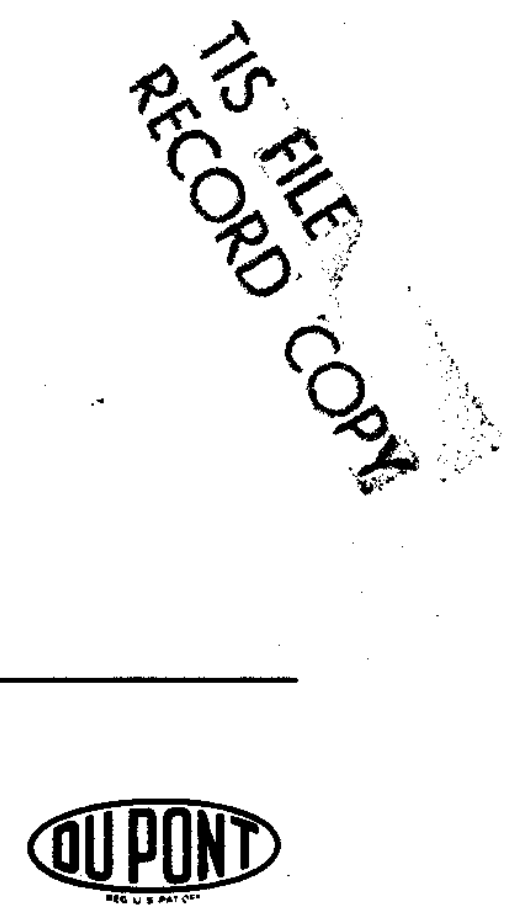

SAVANNAH RIVER LABORATORY AIKEN, SOUTH CAROLINA 29801 


\section{NOTICE}

This report was prepared as an account of work sponsored by the United States Government. Noither the United States nor the United States Energy Research and Development Administration, nor any of their contractors, subcontractors, or their employees, makes any warranty, express or implied, or assumes any legal liability or responsibility for: the accuracy, completeness or usefulness of any information, apparatus, product or process disclosed, or represents that its use would not infringe privetely owned rights.

$\checkmark$

Printed in the United States of America

Available from

National Technical Information Service

U. S. Department of Commerce

5285 Port Royal Road

Springfield, Virginia 22161

Price: Printed Copy \$4.00; Microfiche \$2.25 
DP-1395

Distribution Category: UC-41

663120

\section{REMOVAL OF MERCURY FROM AQUEOUS SOLUTIONS BY SHREDDED RUBBER}

by

E. R. RUSSELL

Approved by

W. H. Hale, Jr., Research Manager

Separations Chemistry Division

Publication Date: October 1975

E. I. DU PONT DE NEMOURS AND COMPANY

SAVANNAH RIVER LABORATORY

AIKEN, SOUTH CAROLINA 29801

PREPARED FOR THE U. S. ENERGY RESEARCH AND DEVELOPMENT AOMINISTAATION UNDER CONTRACT AT (07-21-1 
Shredded or ground rubber absorbs mercury from aqueous solutions. Mercury concentration was reduced from $100 \mathrm{ppm}$ to less than detectable levels ( $5 \mathrm{ppm}$ ) by passing the solution through a column of finely divided tire rubber. Treatment of the rubber with sulfide solutions increases mercury removal capacity by $25 \%$. Mercury cannot be eluted quantitatively, but may be recovered by destructive distillation of the rubber. 


\author{
Introduction 5 \\ Exploratory Batch Experiments 6 \\ Column Operations 6 \\ Mercury Absorption at Various Acidities 7 \\ Recovery of Absorbed Mercury 7 \\ Increased Mercury Removal Capacity 7 \\ Acknowledgment 9 \\ References 9
}


REMOVAL OF MERCURY FROM AQUEOUS SOLUTIONS BY SHREDDED RUBBER

\section{INTRODUCTION}

Mercury contamination of waste waters has become a major environmental concern in recent ycars because fish have been found to accumulate mercury from contaminated waters. Mercury must therefore be removed from solutions that will enter the aquatic environment. The study reported here was made to evaluate the use of waste rubber, which is plentifully available from discarded auto tires, for removing mercury from aqueous solutions.

Rubber is a complex polymeric substance formed from vulcanization of latex. During the vulcanization process sulfur is incorporated into the structure, thereby forming sulfur-sulfur and sulfur-hydrogen bonds. The percentage of sulfur varies according to the use for which the rubber is intended; automobile tire rubber contains about $1 \%$ sulfur. Organic sulfides and mercaptans react readily with mercury or mercuric ion; thus the rubber structure suggests that dissolved mercury contacted with rubber would bond to it via a mercury sulfide linkage and be removed from solution. Since rubber is hydrophobic and not porous, it must be finely divided to expose the maximum surface area for efficient reaction with dissolved mercury.

Rubber has been converted to an ion exchange material by several techniques. I In one method the rubber was treated with concentrated sulfuric acid to produce a sulfonated ion exchanger A1ternatively, the rubber was degraded and converted to an ash that had ion exchange properties. Another method ${ }^{2}$ for forming a mercury-absorbing ion exchanger involves chemical addition of (-C-SH) groups to polymer structures. These processes all involve chemical processing that adds to the cost and process complexity. The process described here makes use of tire rubber as discarded, with minimal pre-treatment.

The techniques described below were demonstrated successfully in engineering studies of removal of mercury from waste solutions at the Savannah River Plant. ${ }^{3}$ 


\section{EXPLORATORY BATCH EXPERIMENTS}

Shredded rubber was obtained initially by filing rubber laboratory stoppers; all subsequent work was performed with shredded rubber obtained from a tire retreading plant. In initial tests, one gram of rubber filings was added to $200 \mathrm{ml}$ of $0.001 \mathrm{M} \mathrm{HNO}_{3}$ containing $1.53 \mathrm{mg} \mathrm{Hg}{ }^{2+} / \mathrm{m} 1$. The solution was shaken for $30 \mathrm{~min}-$ utes, and a sample was taken for atomic absorption analysis. The product contained $1.35 \mathrm{mg} \mathrm{Hg}{ }^{2+} / \mathrm{ml}$. Allowing the solution to stand in contact with rubber for one week with intermittent shaking reduced the mercury concentration to $0.9 \mathrm{mg} \mathrm{Hg}^{2+} / \mathrm{ml}$. The rubber was not completely wetted in the first 30 minutes, but appeared to be so after one week standing.

The relatively slow uptake of mercury apparently results from incomplete wetting of the rubber. In order to demonstrate that the mercury was tightly absorbed, the rubber was thoroughly washed with water and analyzed for mercury content. The washed rubber contained $75 \mathrm{mg} \mathrm{Hg} / \mathrm{g}$ of rubber, or about half of the total mercury originally added.

Hard rubber (ground ebonite) was also tested as an absorbent but was difficult to wet. The maximum absorption of mercury on this material was only about $8 \mu \mathrm{g} / \mathrm{g}$ rubber, and no further tests were made.

\section{COLUMN OPERATIONS}

Since batchwise contact with rubber removes only a portion $(10 \%$ to $50 \%)$ of the mercury from solution, a multistage process is required for quantitative mercury removal. This is most readily achieved by column techniques. While the reaction between mercuric ion and the organic sulfide is fast, the overall rate of reaction is limited by incomplete wetting and perhaps also by diffusion into crevices. As the results of exploratory batch experiments indicated, wetting and pore penetration after the initial rapid uptake of mercury are rather slow.

Prior to the column experiments, a batch experiment was run to estimate an effective residence time in the column for the batch of rubber used. A ten-minute equilibration of $100 \mathrm{~m} 1$ of solution containing $60 \mathrm{\mu g}$ of $\mathrm{Hg}^{2+} / \mathrm{ml}$ with $0.5 \mathrm{~g}$ of shredded rubber reduced the $\mathrm{Hg}^{2+}$ concentration to $31 \mu \mathrm{g} / \mathrm{ml}$. Accordingly, a small column containing shredded rubber from the same batch was used to remove mercury from $200 \mathrm{~m} 1$ of the same solution with the flow adjusted to give a ten-minute residence time (see Table 1). Mercury was not detectable in the column effluent $(<5 \mu \mathrm{g} / \mathrm{m} 1)$. 


\section{MERCURY ABSORPTION AT VARIOUS ACIDITIES}

Since the acidity of waste waters containing $\mathrm{Hg}^{2+}$ can vary considerably, absorption of $\mathrm{Hg}^{2}$ from dilute acid and neutral solutions was compared using the batch contact method. The data in Table 2 indicate that more mercury is absorbed from very slightly acidic solutions $\left(10^{-3} \mathrm{M}\right)$ than from neutral solutions or those higher in $\mathrm{HNO}_{3}$.

\section{RECOVERY OF ABSORBED MERCURY}

The value of mercury recovered from dilute solutions is generally much less than the recovery cost. However, safe disposal of mercury-contaminated rubber may be difficult, so recovery of mercury from the rubber is desirable.

Several unsuccessful attempts were made to elute absorbed mercury from shredded rubber. No more than $66 \%$ of the absorbed mercury could be removed from rubber with $2 \mathrm{M} \mathrm{HNO}_{3}-2 \% \mathrm{H}_{2} \mathrm{O}_{2}$. Elutions by other reagents such as $0.5 \mathrm{M}$ sodium polysulfide, $7 \mathrm{M} \mathrm{HNO}_{3}$, and $1 \mathrm{M} \mathrm{Na}_{2} \mathrm{CO}_{3}$ were less complete.

Destructive distillation of rubber containing absorbed mercury was tested as a method for improving mercury recovery. Heating the material to $250-300^{\circ} \mathrm{C}$ in air yielded oils, a disposable white ash, and approximately $100 \%$ of the mercury in elemental form. In several tests the volatile fraction was collected by bubbling through water; mercury sank to the bottom of the vesse 1 as small droplets, and the oils floated. Such a process could recover both mercury and the potentially useful oils in a relatively pure form.

\section{INCREASED MERCURY REMOVAL CAPACITY}

As described in the introduction, natural rubber is nonporous and very resistant to wetting. Consequently, few active sites (S-H and S-S bonds) are exposed to the solution. The possibility of an inexpensive wash or treatment that would enhance the wetability or capacity of the rubber was therefore investigated.

This investigation demonstrated that treatment of shredded rubber with a sodium polysulfide solution slightly increases its mercury removal capacity. Rubber treated with hot $1 \mathrm{M} \mathrm{Na}_{2} \mathrm{~S}$ containing 10 grams of powdered sulfur per liter, after a wash to remove excess sulfide, absorbs 10 to $25 \%$ more $\mathrm{Hg}^{2+}$ than untreated rubber. The increased capacity could result from several effects, singly or in combination: better wetability of the rubber, deposition of sulfide in the rubber pores, or incorporation of sulfide into the structure. There was no consistent relationship between the increased amount of $\mathrm{Hg}^{2+}$ absorbed and the duration of exposure of the rubber to the polysulfide solution. 
TABLE ]

Absorption of $\mathrm{Hg}^{2+}$ by a Column of Shredded Rubber ${ }^{a, b}$

Volume of Effluent Concentration, Effluent, $\mathrm{ml} \quad \mathrm{Hg} \mathrm{Hg}^{2} / \mathrm{ml}$

$100 \quad 5^{c}$

$200 \quad 5^{c}$

a. Column: $5 \mathrm{ml}, 10 \mathrm{~cm}$ depth

b. Feed: $200 \mathrm{ml}$ containing $60 \mu \mathrm{H} \mathrm{Hg}^{2+} / \mathrm{ml}$, and $0.001 \mathrm{M} \mathrm{HNO}_{3}$

c. Limit of detection of $\mathrm{Hg}^{2+}$

TABLE 2

Mercury Absorption at Various $\mathrm{HNO}_{3}$ Concentrations ${ }^{a_{2}} h$

Contact Time, min $\mathrm{HNO}_{3}, \mathrm{M} \% \mathrm{Hg}^{2+}$ Absorbed *

$\begin{array}{lll}1 & 0.16 & 21\end{array}$

$\begin{array}{lll}6 & 0.16 & 24\end{array}$

$15 \quad 0.16 \quad 22$

$1 \quad 0.001 \quad 25$

$6 \quad 0.001 \quad 50$

$15 \quad 0.001 \quad 51$

1200

$\begin{array}{lll}15 & 0 & 30\end{array}$

a. Feed: $60 \mu \mathrm{g} \mathrm{Hg}^{2+} / \mathrm{ml}, 100 \mathrm{ml}$

b. Absorbent: $0.5 \mathrm{~g}$ shredded rubber 


\section{ACKNOWLEDGMENT}

E. L. Albenesius conceived the original idea of the use of old rubber tires for absorption of mercury.

\section{REFERENCES}

1. A. S. Behrman. Water Softening Process. U. S. Patent $2,333,142$, November 2, 1943.

2. M. O. Lishevskaya, et al. Method of Removing Metal Values from Solution. U. S. Patent 3,728,103, Apri1 17, 1973.

3. D. W. Tharin. Mercury Removal from Aqueous Process Streams. USAEC Report DP-1343, E. I. du Pont de Nemours \& Company, Savannah River Laboratory, Aiken, SC (1974). 